\title{
Modelling the Effects of Market Orientation Enablers on Business Performance among SMEs in a Developing Country
}

\author{
Dubihlela J. \\ Vaal University of Technology, Faculty of Management Sciences \\ 11 Dick King Street, SE 6, Vanderbijpark, 1911, South Africa \\ Email:job@vut.ac.za \\ Dhurup M. \\ Vaal University of Technology, Faculty of Management Sciences \\ Andries Portgieter Blvd., Vanderbijlpark, 1900, South Africa \\ Email: manilalld@vut.ac.za
}

\section{Doi:10.5901/mjss.2014.v5n16p33}

\begin{abstract}
Whilst studies have contributed to the notion that market orientation and its elements drive business performance, very few research efforts has specifically focussed on the relationship between the enablers of market orientation and business performance. The current study provides a succinct relationship between the enablers of market orientation and the relationship with business performance in small and medium enterprises within a South African context. The study was approached from a quantitative paradigm through a structured questionnaire to examine the relationships. Through confirmatory factor analysis and structural equations path modelling, the results established that enablers of market orientation (market-based rewards, interdepartmental cohesion, owners/managers influence and management risk exposure) influence the business performance of SMEs in the region. A significant positive relationship was noted between market orientation enablers and business performance. These variables need to be further unpacked in order to provide synergy and strength for SMEs to survive in competitive environments
\end{abstract}

Keywords: Market orientaion, enablers, business performance, SMEs, owners, managers

\section{Introduction}

Resulting from a review of literature, the conceptualisations of market orientation have been derived from two complementary perspectives. The perspectives converge on linking the adoption and implementation of market orientation to improved business performance (Ngansathil, 2001:93). The seminal work of Kohli and Jaworski (1990) focuses on organisational activities related to the generation and dissemination of, and response to, market intelligence, and the behavioural perspective of Narver and Slater (1990:21) which focuses on organisational values that encourage behaviours consistent with market orientation. These approaches seem to have gained wide acceptance by many academics and business practitioners and provide the foundation for definitions of market orientation (Gray, Matear, Boshoff \& Matheson, 1998). Kohli and Jaworski (1990) offered an operational definition of market orientation which defined market orientation as an "organisation-wide generation of market intelligence through decision support systems, marketing information systems, marketing research efforts, dissemination of the intelligence across company departments, and organisation-wide responsiveness to the changes taking place in the environment.

SMEs play a far more important role in developing economies than in the industrial countries, since SMEs make a major contribution to socio-political stability. In South Africa, the total economic output of small and medium enterprises (SMEs) is nearly $40 \%$ of gross domestic product (GDP), and this sector employs in excess of 60 per cent of the total labour force (Statistics SA, 2005). Unless South Africa succeeds in promoting SMEs, the country will remain saddled with a huge unemployment problem and, therefore, excessive crime in its various forms (Watson \& Godfrey, 1999). The South African government recognises the importance of this sector in achieving the country's national objectives and is committed to its growth. However, a big gap remains which calls for an understanding of enablers of market orientation for the SMEs in South Africa. All over the world, small and medium enterprises (SMEs) make a remarkable contribution to the GDP, employment and poverty alleviation (Statistics SA, 2005). The statistical approximations from previous surveys 
indicate that the total economic output of micro-enterprises and small and medium enterprises (SMEs) contribute significantly to Gross Domestic Product (GDP) (Edigheji, 2010).

Hence the purpose of the study was to examine the influence of market orientation enablers on business performance among SMEs in a developing country (South Africa).

\section{Literature Review}

The literature review is assembled around the constructs that were reviewed from literature regarding enablers of market orientation and business performance.

\subsection{Determinants and enablers of market orientation}

Determinants and enablers of market orientation refer to those factors that influence the development of a set of attitudes and practices that encompass the market orientation construct (Zebal, 2003). In other words, the determinants and enablers are the fundamental elements generating a favourable environment for adopting and implementing a market orientation. Although various researchers have classified these enablers into various constructs, a review of literature on the enablers seems to point towards these broad variables.

\subsubsection{Managerial influence}

Managers have an important influence on the implementation of market orientation within all forms of organisations. Managers influence both inter-functional coordination and other elements of the internal environment, such as employee encounters, employee perceptions of market orientation, employee knowledge, and organisational commitment (Homburg \& Pflesser, 2000). These elements also impact the approach of management style, mission, goals and strategy to be followed within an organisation. According to Narver and Slater (1990) managers influence various elements for market orientation within organisations to thrive. These elements, inter alia, include creativity, sense of risk, competence, responsibility, long-term horizon, planning, and monitoring achievement of goals (Tomášková, 2009).

\subsubsection{Environmental factors}

The role of environment as an important contingency factor has been long espoused by organisational researchers (Subramanian \& Gopalakrishna, 2001). Maydeu-Olivares and Lado (2003) confirm that business organisations seem to devote significantly greater efforts to analysing the environment and implementing environment focussed strategic actions. The external environment poses challenges for SMEs that often do not have resources to counter the external pressures (Homburg \& Pflesser, 2000). The importance of being market-oriented increases under such conditions because a market-oriented firm has a better understanding of the external environment, and consequently, such firms can better respond to the demands of the external environment (Subramanian \& Gopalakrishna, 2001).

There are three important components of the external environment: competitive intensity, market turbulence and technological turbulence (Jaworski \& Kohli, 1996). Environmental factors relate to market dynamics, competition and technological changes, significantly affecting organisational ability to manage its operations efficiently. Competitive intensity refers to the extent of rivalry among different players in an industry. According to Porter (2008), competitive intensity is an important determinant of the profitability of a firm in a given industry. Market turbulence refers to the level of instability in the external market environment which forces organisations to vary their strategies in the face of changing customer needs (Chen, 1998). The rate of technological change, referred to as technological turbulence, influences efforts by organisations to adopt and implement market orientation. Chen (1998) suggested that organisations actively engaged in changing customer preferences and competitor behaviour, and integrating such knowledge in the operations, outperform their counterparts that neglect technological developments.

\subsubsection{Market-based reward system}

Reward systems can shape the behaviour of employees within the organisation, and hence enable market orientation and enhance business performance (Kohli, Jaworski. \& Kumar, 1993). More clearly, Pulendran, Speed and Widing (2000) affirm that there is a positive correlation between market-oriented operations and reward systems. Based on this assertion, it can be concluded that an organisation implementing the system of rewards based on performance marketing 
will encourage the growth of market orientation within its operations. Various studies have shown that reward systems can be instrumental in shaping employee behaviour (Anderson \& Oliver, 1987; Payne, 1988; Sigauw, Brown \& Widing., 1994). Ngansathil (2001) states that marketing-based reward systems influence the degree of market orientation in both the domestic companies and export companies that perform marketing activities.

\subsection{Business performance}

Business performance (BP) is broadly viewed from two perspectives in the context of market orientation (Chaharbaghi \& Willis, 1999). It is viewed as both an objective measure and a subjective measure. Objective measures of performance are mainly economic, while a subjective measure relates to non-economic aspects of performance. According to Matsuno and Mentzer (2000:8), business performance should be viewed not only as economic performance (concrete absolute figures representing organisational performance) but also as non-economic performance (customer satisfaction, customer retention, social acceptance, corporate image, and employee satisfaction).

The objective business performance approach includes absolute financial aspects of the business such as revenue growth, profit margins, market share, investment returns, assets performance indicators, staff turnover rates and many such financial indicators (Plakoyiannaki, Tzokas, Dimitratos \& Saren., 2008). The economic performance of an organisation is defined by Matsuno and Mentzer (2000) as the function of some financial indicators, such as return on investment, profit, market share, sales volume, revenues, product quality and overall financial position.

The term "subjective" is used to mean that the company's performance score is derived using a scale with anchors such as "very poor" to "very good," or "much lower" to "much higher" compared with competitors, while an "objective" measure would be an actual percentage figure for sales growth or profitability (Doyle, 1995). The subjective performance approach focuses on indicators of business performance mainly relating to competition, market performance and operations (Roomi, Harrison \& Beaumont-Kerridge, 2009). For example, positive customer responses have been associated with the market orientation of organisations (Zebal \& Goodwin, 2012). As Doyle (1995) reasoned, when customers are satisfied with the value being provided in a product they are more likely to repurchase. Kohli and Jaworski (1993) also state that market orientation is related to satisfied customers who both recommend the product to other potential customers and themselves keep repurchasing. They further considered employees' organisational commitment and esprit de corps (team spirit) as non-economic performance (Jaworski \& Kohli, 2000).

Based on the affirmations from literature on the relationship between enablers of market orientation and business performance, the following hypotheses have been set for the study:

$\mathrm{H} 1$ - Market orientation enablers will have a positive significant influence on business performance of SMEs within a South African context.

\section{Research Methodology}

The study made use of a quantitative approach. Quantitative research was chosen because it deals with numbers, employs statistical methods to analyse data and is associated with the positivist research perspective and testing of hypothesis (Sedmak \& Longhurst, 2010). Quantitative research allows the use of questionnaires to collect data and controls bias by using randomised sampling methods.

\subsection{Sampling}

A list of registered SMEs was drawn up from the databases of the Small Enterprise Development Agency (SEDA), the Gauteng Enterprise Propeller (GEP) and Emfuleni Municipality in the Vaal Triangle region. The Small Business Directory of the Vaal Triangle was also used in order to gain access to a representative sample. The sampling frame was constituted of small and medium-sized enterprises only. Major towns represented in this demarcation included Vereeniging, Sasolburg and Vanderbij|park. Based on past research studies by Lynn Lipp, Akgun and Coertez (2002) and Becherer, Halstead and Haynes (2003), a sample size of 300, was deemed appropriate. The chosen sample size was large enough to form a good representation of SMEs in the Vaal Triangle. The sample size was also consistent with empirical studies undertaken by Van Egeren and O'Connor (1998), Advani and Borins (1998), Shoham, Rose and Kropp (2005) and White and Simas (2008).

Owners/managers and senior managers were included as part of the sample because their involvement in the dayto-day operations of the business who had a better perception of the market than alternative informants (Shoham et al. 2005). The respondents had to be operating in the Vaal Triangle, and actively operating the SMEs. 


\subsection{Instrumentation and data collection}

Demographic and business profile information was used to gather basic information about the participants including age, gender, highest level of education, market base of the organisation and number of full time employees. Enablers of market orientation were measured on item scales that were developed by Bhuian (1998); Pulendran et al. (2000) and Zebal (2003). In order to measure business performance, scale items were derived from the work of a variety of authors, as these items have been successfully used in other developing countries for measuring business performance (AppiahAdu, 1998; Akimova, 2000). These economic performance items include return on investment (Ruekert \& Walker, 1987), profit (Perreault., Cannon \& Mccarthy, 2011), sales growth and market share (Aaker, 1998), sales volume (Borucki \& Burke, 1999), as well as revenues, product quality, and financial position (Bhuian, 1998). For non-economic performance items, this study followed the work of Kumar (2009). The constructs of organisational commitment and esprit de corps were measured by scales developed by Jaworski and Kohli (1993). These scales were used because of their wide acceptance in the market orientation literature.

Data was collected by using a predesigned structured questionnaire in 2013 through the use of trained fieldworkers. Participants were informed of the purpose of the study. Participation was voluntary and no incentives were provided.

\section{Findings and Discussion}

\subsection{Sample composition}

The profile of sampled respondents in the survey comprised 199 males and 74 females (representing $72.9 \%$ and $27.1 \%$ respectively). The age structure of the sample, shows that only $14.7 \%(n=40)$ of the respondents were under the age of 30 years, 25.6\% ( $n=70)$ were aged between 30 and 39 years, 17.2\% ( $n=47)$ represented the $50-59$ year age group, and $2.9 \%(n=8)$ of the sample were 60 years of age and above. In terms of formal education levels, three quarters $(33.3 \%+28.9 \%+12.5 \%=74.7 \%)$ of the respondents had at least a tertiary qualification. The remaining $25.3 \%$ of the sample represented entrepreneurs possessing either basic education $(3.7 \%+20.1 \%=23.8 \%)$ or no formal education $(1.5 \%)$ at all. Majority of SME businesses employed fewer than 50 employees.

\subsection{Confirmatory factor analysis and model fit assessments}

According to Anderson and Oliver (1987), prior to testing the hypotheses, confirmatory factor analysis (CFA) was performed to confirm accuracy of the multiple-item constructs measures. The AMOS programme, version 21.0 was used. A confirmatory measurement or confirmatory factor analysis model, specifies the relations of the observed measures to their posited underlying constructs, with the constructs allowed to inter-correlate freely (Chen, 1998). Initial specification search led to the deletion of the items that were less than the recommended 0.5 . This was done to provide for an acceptable fit and the resultant scale accuracy.

Acceptable model fit was indicated by chi-square value over degree of freedom ( $\chi 2 / \mathrm{df}$ ) of value between 1 and 3 , the values of Goodness-of-Fit Index (GFI), Comparative Fit Index (CFI), Incremental Fit Index (IFI), and Tucker-Lewis Index (TLI) equal to or greater than 0.90; and the Root Mean Square Error of Approximation (RMSEA) value equal to or less than 0.08. The overall observed data fits the model reasonably well (CFA model fit results) as it is within the recommended statistics for the final overall-model assessment. All the indicators showed acceptable fit of the measurement model for the dataset. Over and above the acceptable correlation values $(0.394<$ Cor $>0.800)$, the measurement model produced a ratio of chi-square value over degree-of-freedom of 2,850 and GFI, CFI, IFI, TLI and RMSEA of $0.931,0.919,0.921,0.900$, and 0.058 respectively.

\subsection{Reliability and validity}

Three methods i.e. Cronbach's alpha test, composite reliability test (CR) and average value extracted test (AVE) were used to check the reliability of the research measures (Cronbach, 1951). Table 1 and Table 2 show the results of all these three tests used to check the research measure reliability. Churchill and lacobucci (2005), and Nunnally (1978) recommended that, for scale items used for the first time in a new environment, the cut off value for the alpha coefficient should be 0.700 . The Cronbach alpha values for each of the scales making up latent variables (enablers and business performance) were computed. Table 1 provides evidence that each of the scales exhibit satisfactory reliability with values 
ranging from 0.703 to 0.902 .

Table 1: Summary of Cronbach's alpha reliability results

\begin{tabular}{|c|c|c|c|c|c|}
\hline Scale & No. of Items & Cronbach's Alpha & Dimensions/factors & No. of items & Cronbach's Alpha \\
\hline \multirow{4}{*}{ Enablers of Market Orientation } & \multirow{4}{*}{12} & \multirow{4}{*}{0.767} & Market-based reward system & 4 & 0.8031 \\
\hline & & & Interdepartmental connectedness & 3 & 0.7733 \\
\hline & & & Top management emphasis & 3 & 0.7433 \\
\hline & & & Management risk posture & 2 & 0.7631 \\
\hline \multirow{3}{*}{ Business Performance } & \multirow{3}{*}{19} & \multirow{3}{*}{0.904} & Financial performance & 9 & 0.9023 \\
\hline & & & Customer satisfaction \& loyalty & 6 & 0.7643 \\
\hline & & & Organizational commitment & 4 & 0.7031 \\
\hline
\end{tabular}

The second measure of internal consistency is the composite reliability (CR) coefficient. The CR coefficient does not assume that all indicators are equally weighted (Chen, 1998). Interpreted like a Cronbach's alpha, the CR measure of 0.70 is a threshold for "modest" composite reliability (Churchill \& lacobucci, 2005).

Table 2: Accuracy analysis statistics

\begin{tabular}{|c|c|c|c|c|c|c|c|c|c|}
\hline \multirow{2}{*}{\multicolumn{2}{|c|}{ Research Constructs }} & \multicolumn{2}{|c|}{$\begin{array}{l}\text { Descriptive } \\
\text { Statistics* }\end{array}$} & \multicolumn{2}{|c|}{ Cronbach's Test } & \multirow[t]{2}{*}{ C.R. } & \multirow[t]{2}{*}{ AVE } & \multirow[t]{2}{*}{ Factor Loading } & \multirow[t]{2}{*}{ Highest S.V. } \\
\hline & & Mean & SD & Item-total & a Value & & & & \\
\hline \multirow{16}{*}{$\begin{array}{l}\text { Business Performance } \\
\text { (BP) }\end{array}$} & $\mathrm{IBP}-1$ & \multirow{16}{*}{3.830} & \multirow{16}{*}{0.690} & 0.587 & \multirow{16}{*}{0.915} & \multirow{16}{*}{0.947} & \multirow{16}{*}{0.437} & 0.782 & \multirow{16}{*}{0.262} \\
\hline & $\mathrm{I}_{\mathrm{BP}-2}$ & & & 0.651 & & & & 0.764 & \\
\hline & $\mathrm{I}_{\mathrm{BP}-3}$ & & & 0.721 & & & & 0.687 & \\
\hline & $\mathrm{IBP}-4_{\mathrm{B}}$ & & & 0.623 & & & & 0.695 & \\
\hline & $\mathrm{I}_{\mathrm{BP}-5}$ & & & 0.612 & & & & 0.675 & \\
\hline & $\mathrm{IBP}-6$ & & & 0.707 & & & & 0.680 & \\
\hline & $\mathrm{IBP}-7$ & & & 0.649 & & & & 0.698 & \\
\hline & $I_{\mathrm{BP}-8}$ & & & 0.646 & & & & 0.624 & \\
\hline & $\mathrm{IBP}-9$ & & & 0.506 & & & & 0.719 & \\
\hline & $\mathrm{I}_{\mathrm{BP}-10}$ & & & 0.525 & & & & 0.644 & \\
\hline & $\mathrm{I}_{\mathrm{BP}-11}$ & & & 0.709 & & & & 0.623 & \\
\hline & $\mathrm{I}_{\mathrm{BP}-12}$ & & & 0.542 & & & & 0.539 & \\
\hline & $\mathrm{I}_{\mathrm{BP}-13}$ & & & 0.633 & & & & 0.543 & \\
\hline & $\mathrm{I}_{\mathrm{BP}-14}$ & & & 0.631 & & & & 0.503 & \\
\hline & $\mathrm{I}_{\mathrm{BP}-15}$ & & & 0.593 & & & & 0.500 & \\
\hline & $\mathrm{I}_{\mathrm{BP}-16}$ & & & 0.588 & & & & 0.500 & \\
\hline \multirow{3}{*}{ Enablers of MO (EMO) } & IDMO-1 & \multirow{3}{*}{3.973} & \multirow{3}{*}{0.803} & 0.543 & \multirow{3}{*}{0.743} & \multirow{3}{*}{0.728} & \multirow{3}{*}{0.497} & 0.996 & \multirow{3}{*}{0.405} \\
\hline & IDMO-2 & & & 0.594 & & & & 0.500 & \\
\hline & IDMO-3 & & & 0.571 & & & & 0.500 & \\
\hline
\end{tabular}

Note: BP = Business Performance; EMO = Enablers of Market Orientation; AVE: Average Variance Extracted; * Scores: 1 Strongly Disagree; 5 - Strongly Agree C.R = Composite Reliability.

The CR results shown in Table 2 were used to test the internal consistency of the measurement model. The higher level of CR coefficient demonstrated higher reliability of the scale. The item-to-total values ranged from 0.506 to 0.833 and, were above the cut-off point of 0.3 (often $\leqq 0.3$ ) recommended by Dunn, Seaker and Waller (1994). The Composite Reeliability (CR) values ranged from 0.728 and 0.947 . The results indicate that all the CR values exceeding the threshold of 0.70 recommended in literature (Chen, 1998; Nunnally, 1978) and therefore, confirm that the measures used in this study are reliable.

The third reliability test was the average variance extracted (AVE) with the results also indicated in Table 2. The average variance extracted (AVE) estimates (see Table 2) reflected that the overall amount of variance in the indicators were accounted for by the latent construct (Neuman, 2006). Higher values for the AVE (greater than 0.40) reveal that the 
indicators well represented the latent construct. Overall, all average variance explained (AVE) values were above 0.4, thus acceptable according to the literature (Fraering \& Minor, 2006). These results provided evidence for acceptable levels of research scale reliability.

Convergent validity was assessed by checking if individual item loadings for each corresponding research construct was above the recommended value of 0.50 (Aldalaigan \& Buttle, 2002). Table 2, show that the factor loadings ranged from 0.506 to 0.721 . Therefore, all the items finally used had loadings of more than the recommended 0.50 , indicating acceptable individual item convergent validity (Dunn et al., 1994).

One of the method used to check on the discriminant validity of the research constructs was the evaluation of whether the correlations among latent constructs were less than 1.0 (Nunnally, 1978). As indicated in Table 3, the intercorrelation values for all paired latent variables are less than 1 , indicating the existence of discriminant validity.

Table 3: Correlations between constructs

\begin{tabular}{|c|c|}
\hline Research Construct & Business performance (BP) \\
\hline Enablers of Market Orientation (EMO) & 0.712 \\
\hline
\end{tabular}

Discriminant validity was further established by checking and confirming that the AVE values were greater than the highest shared variance values (Nunnally, 1978). Table 2 show that all the average value extracted (AVE) are above the shared variance values (SV) for all the research constructs, therefore further confirming the existence of discriminant validity.

\subsection{Structural path model}

A structural equation modeling (SEM) was undertaken using AMOS 21.0 statistical software programme. Following a twostep model building (Anderson \& Oliver, 1987), the measurement model was assessed prior to testing the structural model. Bentler (1990) recommends the use of the maximum likelihood estimation (MLE) method particularly because it has desirable asymptotic properties such as the minimum variance and has no biasedness (Browne \& Cudeck, 1993).

The text output results for the structural equation analysis for the model fit are also reported in Figure1. The results for the model fit show that the model is acceptable in terms of overall goodness of fit measures. Acceptable model fit are indicated by CMIN/DF value $<3$; RMSEA values $\leqq 0.080 ; \mathrm{GFI}, T L I$ and CFI values $\geqq .90$. The study's test results indicate that, CMIN/DF (2.620); GFI (0.901); IFI (0. 911), TLI (0.900), CFI (0.900), and RMSEA (0.060). These results are within acceptable levels, suggesting achieved thresholds (Browne \& Cudeck, 1993; Marsh, Wen \& Hau, 2004). This suggests that the model converged well and could be a plausible representation of underlying empirical data structures collected in a South African setting.

The parameter estimates of the structural model exhibited the direct effects of market orientation enablers on business performance. Significant coefficients at $p<0.001$ level affirm positive significant relationships among latent constructs, namely market orientation enablers and business performance.

The corresponding path coefficients of the research hypotheses posited observable existence of positive relationships between the enablers of market orientation and market orientation business performance. The hypothesis $H_{1}$ - market orientation enablers will have a positive significant influence on business performance of SMEs within a South African context is therefore supported as the path coefficient from market orientation enablers to business performance is 0.65 which is significant at $p<0.001$. 
Figure 1: Path model - Market orientation enablers and business performance

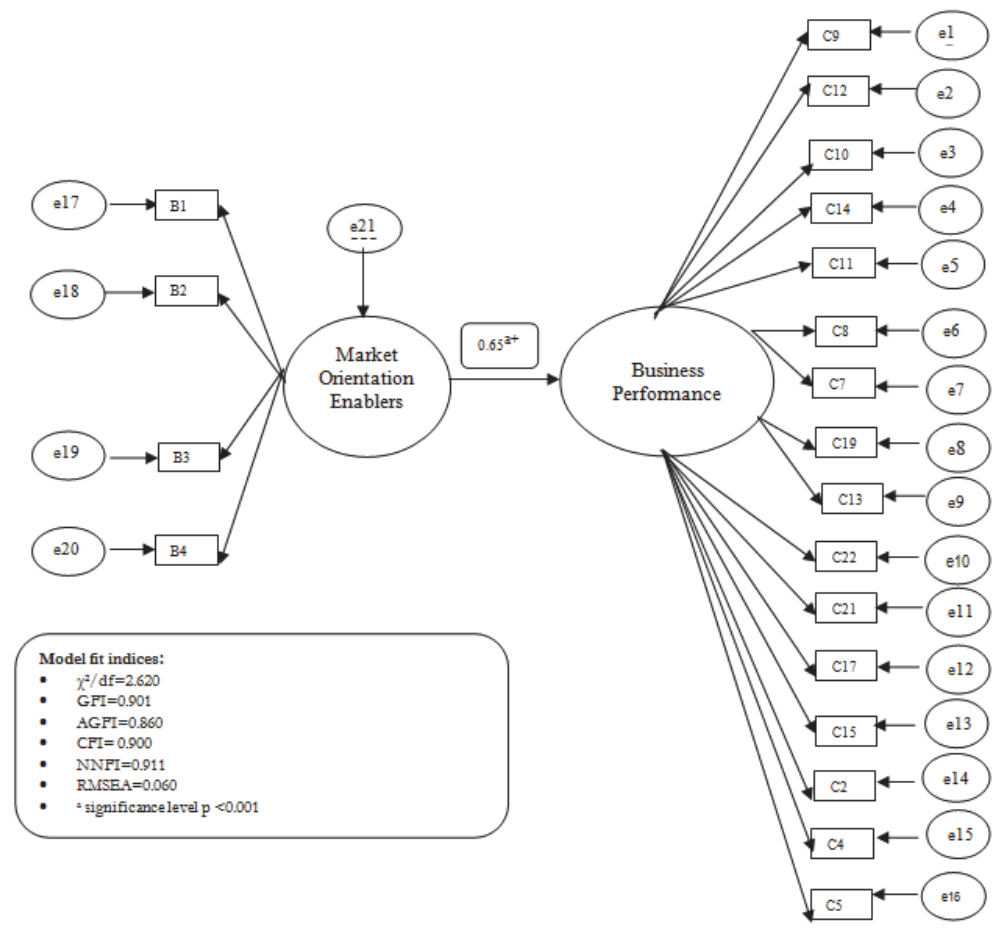

The results of the relationships lend substantial support to the previous findings of Jaworski and Kohi (1993), Slater (2001) and Pelham (2000). These studies confirmed that the enablers of market orientation have a significant positive effect on performance. Although Zebal (2003) groups them together as antecedents of market orientation, their relationship with business performance is identified. Deshpandé (1999) states that market orientation provides a unifying focus for the efforts and projects of individuals and departments within an organisation in order to create superior value for customers, leading to superior performance. In other words, market-oriented SMEs are more likely to succeed if they understand the underlying factors that enable them their market-oriented strategies. Bulent and Seigyoung (2006) claim that "a basic requirement for the development of a market-oriented firm is to create market-based measures of performance". In other words, reliance on market-based factors for evaluating and rewarding managers may trigger overall market orientation of the organisation.

Organisations that evaluate and administer rewards based on customer satisfaction and service levels are more likely to encourage the active generation and dissemination of market intelligence and responsiveness to market needs. Bulent and Seigyoung (2006) suggest that continuous reinforcement by senior management is required if individuals within the organisation are to be encouraged to generate, disseminate and respond to market intelligence. Deshpandé (1999) states that "connectedness enables adequate amounts of intelligence to be generated and also allows for its appropriate utilisation", and that increased inter-departmental connectedness may result in increased overall market orientation and business performance. Jaworski and Kohli (1993) posit that senior management's willingness to take risks will encourage and facilitate organisation-wide commitment to innovation and responsiveness. On the other hand, a riskaversion policy adopted by senior management will tend to inhibit innovativeness and the creative processes of employees. Accordingly, Zebal (2003) views organisations whose management are high risk takers as more likely to be market oriented and improve business performance than those organisations whose management are risk averse.

\section{Conclusion}

The results indicate that the enablers to market orientation significantly influence business performance. By implication, this finding indicates that market-oriented SMEs are more likely to perform better than those SMEs that are not market 
oriented. Understanding market orientation dimensions is a prerequisite for delivering superior business performance. Market orientation has been recognised as a strategic tool for achieving operational efficiency and improved positive organisational performance. Notwithstanding such affirmations, the frameworks developed by Jaworski and Kohli (1993) and Narver and Slater (1990) provide an interesting avenue for gaining a comprehensive understanding of the market orientation dimensions. The applicability of the market orientation framework in a South African setting confirms the potential of using this framework for other developing economies.

\section{References}

Aaker, D.A. 1998. Strategic market management. $5^{\text {th }}$ edition. New York: Wiley.

Advani, A., \& Borins, S. 2001. Managing airports: A test of the new public management. International Public Management Journal, 4(1):91-107.

Akimova, I. 2000. Development of market orientation and competitiveness of Ukrainian firms. European Journal of Marketing, 34(9):1128-1148.

Aldalaigan, A. H. \& Buttle, F. A. 2002. System and Transactional Service Quality scale (SYSTRA-SQ): A new measure of bank service quality. Industrial Journal of Service Industry Management, 13(3):362-381.

Appiah-Adu, K. (1998). Market orientation and performance: Empirical tests in a transition economy. Journal of Strategic Marketing, 6:25-45.

Anderson, E. \& Oliver, R. L.1987. Perspectives on behaviour-based versus outcome-based sales force control systems. Journal of Marketing, 3(4):76-88

Becherer, C. R., Halstead, D. \& Haynes, P. 2003. Marketing orientation in SMEs: effects on the internal environment. New England Journal of Entrepreneurship, 6 (1):13-22.

Bentler, P. M. (1990). Comparative fit indexes in structural models. Psychological Bulletin 107, 238-246.

Bhuian, S. N. (1998). An empirical examination of market orientation in Saudi Arabian manufacturing companies. Journal of Business Research, 43:13-25.

Borucki, C. C. \& Burke, M. J. 1999. An examination of service-related antecedents of retail store performance. Journal of Organizational Behavior, 20:943-962.

Browne, M. W., \& Cudeck, R. (1993). Alternative ways of assessing model fit. In K. A. Bollen \& J. S. Long (Eds.), Testing structural equation models(pp. 136-162). Newbury Park, CA: Sage

Bulent, M. \& Seigyoung, A. (2006). Creating a firm level dynamic capability through capitalizing on Market Orientation and Innovativeness. Journal of the Academy of Marketing Science, 34 (1):63-73.

Chaharbaghi, K. \& Willis, R.1999. Study and practice of sustainable development. Engineering Management Journal, 9(1):41-48.

Chen, C. 1998. Market Orientation of small and medium sized firms in Taiwan. Journal of Small Business Management, 36 (3): 79-85.

Churchill, G.A. \& lacubucci, D. 2005. Marketing Research. Methodological Foundations. 9th edition. Ohio: Thomson Corporation.

Cronbach, L.J. 1951. Coefficient alpha and the internal structure of tests. Psychometrika, 16(3):297-333.

Deshpandé, R. (1999). 'Foreseeing' marketing. Journal of Marketing, 63: 164-167.

Doyle, P. 1995. Marketing in the new millennium. European Journal of Marketing, 29(13):23-41.

Dunn, S. C., Seaker, R. F. \& Waller, M. A. 1994. Latent variables in business logistics research: Scale development and validation. Journal of Business Logistics, 15 (2): 145-172.

Edigheji, O.E. (2010). Constructing a democratic developmental State in South Africa: Potentials and Challenges. Cape Town: Human Science Research Council Press.

Fraering, M \& Minor, MS. 2006. Sense of community: An exploratory study of US consumers of financial services. International Journal of Bank Marketing 24(5):284-306.

Gray, B., Matear, S., Boshoff, C. \& Matheson, P. 1998. Developing a better measure of market orientation. European Journal of Marketing, 32(10): 884-903.

Homburg, C. \& Pflesser, C. (2000). A multiple-layer model of market oriented organisational culture: measurement issues and performance outcomes. Journal of Marketing Research 37(4):449-462.

Jaworski, B. J. \& Kohli, A. K. 1993. Market orientation: Antecedents and consequences. Journal of Marketing. 57:53-70.

Jaworski, B.J. \& Kohli, A.K. 1996. Market orientation: review, refinement and roadmap. Journal of Market-focused Management, (1):119135.

Jaworski, B.J. \& Kohli, A.K. (2000). Market-driven versus driving markets. Journal of the Academy of Marketing Science, 28 (1):45-54.

Kohli, A.K. \& Jaworski, B.J. 1990. Market orientation: The construct, research propositions, and managerial implications. Journal of Marketing, 54 (1):1-18.

Kohli, A. K., Jaworski, B.J. \& Kumar, A. 1993. MARKOR: A Measure of market orientation. Journal ofMarketing Research, 30 (4): 46777.

Kumar, N. (2009). How emerging giants are rewriting the rules of M\&A. Harvard Business Review, 87 (5):115-121.

Lynn, G. S., Lipp, M. S., Akgun, E. A. \& Coertez, A. 2002. Factors impacting the adoption and effectiveness of the World Wide Web in Marketing. Industrial Marketing Management Journal, 31(1): 35-49.

Maydeu-Olivares, A. \& Lado, N. 2003. Market orientation and business economic performance: A mediational model. International 
Journal of Service Industry Management, 14(3):284-309.

Marsh, H.W., Wen, Z., \& Hau, K-T. (2004). Structural equation models of latent interactions: Evaluation of alternative estimation strategies and indicator construction. Psychological Methods, 9, 275-300.

Matsuno, K. \& Mentzer, J.T. 2000. The effects of strategy type on the market orientation-performance relationship. Journal of Marketing, 64(4):1-16.

Narver, J. C. \& Slater, S. F. (1990). The effect of a market orientation on business profitability. Journal of Marketing, 54 (4):20-35.

Neuman, L. W. 2006. Social research methods: Qualitative and quantitative approaches. $6^{\text {th }}$ edition. Boston:Pearson International Education.

Ngansathil, W. 2001. Market orientation and business performance: Empirical evidence from Thailand. Melbourne: The University of Melbourne( PHD- thesis).

Payne, A.F. 1988. Developing a marketing-oriented organization. Business Horizons-May/June, (1):46-53.

Pelham, A.M. (2000). Market orientation and other potential influences on performance in small and medium-sized. Journal of Small Business Management, 38(1):45-67.

Perreault, W., Cannon, J. \& Mccarthy, E. (2011). Basic Marketing. 18th edition. Homewoods: McGraw-Hill.

Plakoyiannaki, E., Tzokas, N., Dimitratos, P. \& Saren, M. 2008. How critical is employee orientation for customer relationship management? Insights from a case study. Journal of Management Studies, 45(2):268-293.

Porter, M. E. 2008. The Five Competitive Forces that Shape Strategy. Harvard Business Review, (1):86-104.

Pulendran, S., Speed, R. \& Widing, R.E. 2000. Antecedents and consequences of market orietation in Australia. Australian Journal of Management, 25(2):119-143.

Roomi, M. A., Harrison, P. \& Beaumont-Kerridge, J. (2009). Women-owned small and medium enterprises in England: Analysis of factors influencing the growth process. Journal of Small Business and Enterprise Development, 16(2): 270-288.

Ruekert, R. W. \& Walker, O. C. (1987). Marketing's interaction with other functional units: A conceptual framework and empirical evidence. Journal of Marketing, 51(1): 1-19.

Sedmark, M. \& Longhurst, P. 2010. Methodological choices in enterprise systems research. Business Process Management Journal, 16(1): 76-92.

Shoham, A., Rose, G.M. \& Kropp, F. 2005. Market Orientation and Performance: a Meta-Analysis. Marketing Intelligence and Planning, 23(5):435-454.

Sigauw, J.A., Brown, G. \& Widing, R.E. 1994. The influence of the market orientation of the firm on sales force behaviour and attitudes. Journal of Marketing, 31(2):106-16.

Slater, S. F. 2001. Market orientation at the beginning of a new millennium. Managing Service Quality, 11(4):230-232.

Statistics South Africa. 2005. Gross Domestic Product: second quarter 2005. hnp:/lwww..statssa.gov.zalPublicationsiP412nd Quarter2004.pdf Date of access: 7 Aug. 2013.

Subramanian, M. J. \& Gopalakrishna, R. P. (2001). The Market Orientation- Performance Relationship in the Context of a Developing Economy. Journal of Business Research, 53(1):13-18.

Tomášková, E. 2009. Internal barriers of market orientation application. Economic and Management, 14:1-6.

Van Egeren, M. \& O'Connor S. 1998. Drivers of market orientation and performance in service firms. Journal of Services Marketing, 12(1):39-58.

Watson, L.M. \& Godfrey, N.F. 1999. Enterprise support for rural small, medium and micro enterprises (SMMEs) in South Africa. Pretoria: UNISA \& Council for Scientific \& Industrial Research (CSIR).

White, D.W. \& Simas, C.F. 2008. An empirical investigation of the link between market orientation and church performance. International Journal of Nonprofit and Voluntary Sector Marketing.13:153-165.

Zebal, M.A. 2003. A Synthesis Model of Market Orientation for a Developing Country - The Case of Bangladesh. Melbourne: Victoria University (PhD-Thesis).

Zebal, M.A. \& Goodwin, D.R. (2012). Market orientation and performance in private universities. Marketing Intelligence and Planning, 30(3): 339-357. 